IdeAs

Idées d'Amériques

$16 \mid 2020$

Les marges créatrices : intellectuel.le.s afrodescendant.e.s et indigènes auX Amériques, XIX-XXe siècle

\title{
Suffrage during the Pandemics of 1918 and 2020
}

\section{Allison K. Lange}

\section{(2) OpenEdition}

\section{Journals}

Electronic version

URL: http://journals.openedition.org/ideas/9432

DOI: 10.4000/ideas.9432

ISSN: 1950-5701

\section{Publisher}

Institut des Amériques

\section{Electronic reference}

Allison K. Lange, «Suffrage during the Pandemics of 1918 and 2020 », IdeAs [Online], 16 | 2020, Online since 01 October 2020, connection on 18 October 2020. URL : http://journals.openedition.org/ideas/ 9432 ; DOI : https://doi.org/10.4000/ideas.9432

This text was automatically generated on 18 October 2020

\section{c) (i)}

IdeAs - Idées d'Amériques est mis à disposition selon les termes de la licence Creative Commons Attribution - Pas d'Utilisation Commerciale - Pas de Modification 4.0 International. 


\title{
Suffrage during the Pandemics of 1918 and 2020
}

\author{
Allison K. Lange
}

1 In October 1918, a suffragist named Florence Huberwald declared to the New Orleans Times-Picayune: "Everything conspires against woman suffrage" ("Influenza," 1918). That month, she and many other activists watched as the number of flu cases in the United States rose. When I encountered her quote in April 2020, I could relate to her experience in a way that I could not have imagined a few months before. Huberwald had plans, and she saw them collapsing. I, too, had plans, but fellow scholars, museums, historical societies, and numerous other organizations slowly realized that the events we had organized to mark the $19^{\text {th }}$ Amendment's centennial needed to be changed. Crises like these are movements of destruction, but they are also opportunities to create something new. The 1918 flu pandemic might have delayed the passage of the $19^{\text {th }}$ Amendment, but women's work during the crisis might have also ensured support for the measure.

2 By the time Huberwald made her remarks in the fall of 1918, women's voting rights activists had launched a popular visual campaign to emphasize that women were important caregivers. Beginning in the 1890s, the National American Woman Suffrage Association (NAWSA) and the National Association of Colored Women (NACW) emphasized that women needed the vote to be better mothers. They challenged over a century of their opponents' imagery and cartoons that contended that female voters would become masculine and abandon their motherly, domestic duties. While the NACW had few resources to develop a propaganda campaign to popularize this message, NAWSA, the largest suffrage organization, did. By the 1910s, they had a national press committee, a publishing company, publicity professionals, and a corps of female artists to create a powerful visual campaign. 


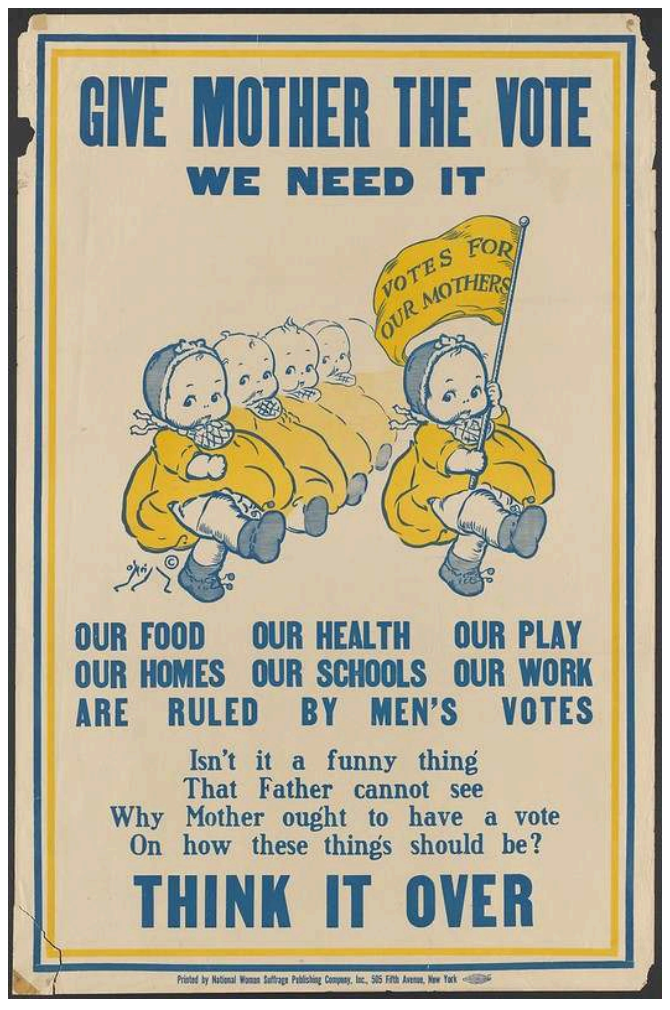

ca. 1915, Poster Collection, Schlesinger Library, Radcliffe Institute, Harvard University.

3 One NAWSA poster by Rose O'Neill captures the type of imagery that the group distributed. This 1915 poster features four babies marching with a "Votes for our Mothers" banner. They wear suffrage yellow beneath the poster's title: "Give Mother The Vote We Need It." The poster notes that women's votes would improve the lives of these children through their schools, health, and food. NAWSA emphasized that white women - especially those wealthy enough to not work and focus on their families needed the vote. Their message emphasized that white women's votes would reinforce the existing gender, class, and racial and hierarchies, not disrupt them. 


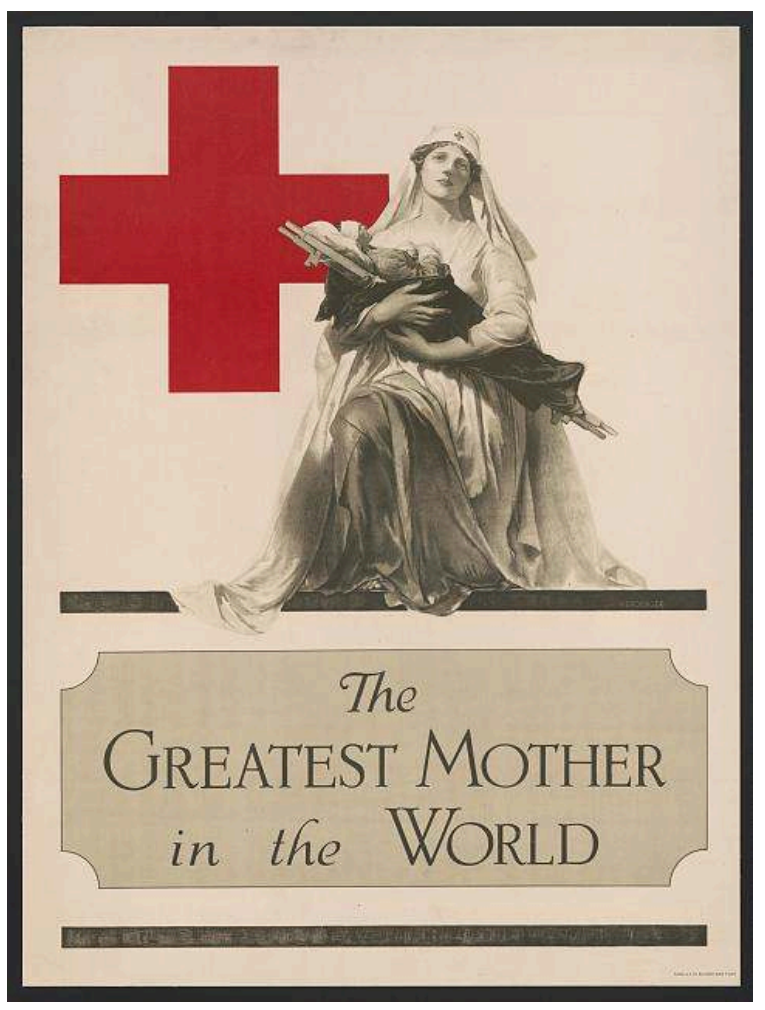

1917, lithograph produced for the American Red Cross, Library of Congress

4 In response to this prominent campaign, in 1917 the United States government's Committee on Public Information and other organizations employed similar visual themes to call on women to support the nation's entry into World War I. For example, one famous poster from 1917 adapted NAWSA's imagery of idealized white mothers. The poster by Alonzo Foringer centers on a larger-than-life young white female nurse in flowing white robes. She looks up while she cradles a wounded soldier on a stretcher. The pair resemble traditional Christian imagery of the Virgin Mary and baby Jesus. As the title declares, this woman is the "The Greatest Mother in the World," crucial to nation's future. Artists created numerous posters with similar imagery because they and the officials who commissioned them - believed it resonated with the public. As with NAWSA's propaganda, the pictures demonstrated that women needed to offer their supposedly innate caregiving skills to support the nation. 


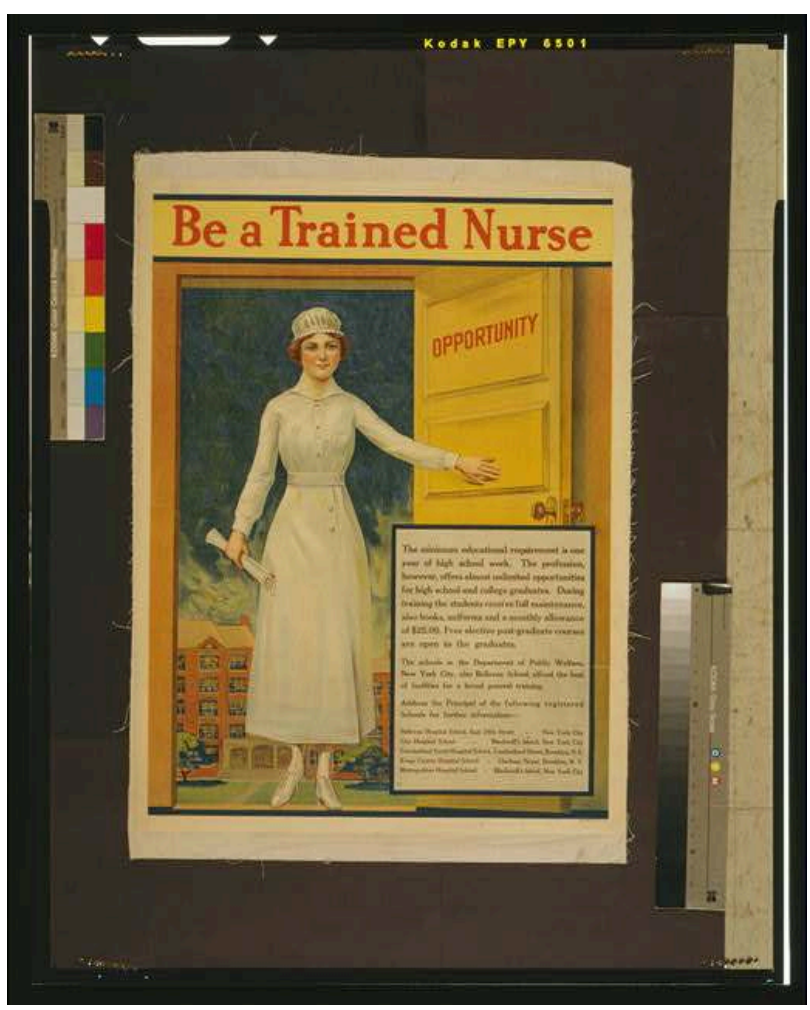

1917 or 1918, lithograph poster, Library of Congress

5 Anti-suffragists had long made the argument that women should not vote because they could not fight for their country. Women's voting rights activists wanted to prove that, even outside of combat roles, women's work made them valuable citizens. Suffragists responded by joining as nurses, farming to produce crops for hungry soldiers and civilians, and working in factories to produce supplies.

Imagery emphasized that the war provided opportunities too. This poster by the New York Department of Public Welfare illustrates the fact female workers had access to new opportunities during the war. A white woman in a clean nurse's uniform opens a door labeled "Opportunity." She has a diploma in hand, presumably from the nursing school behind her. The poster seeks to encourage young women "with at least one year of high school work" to attend. The institutions provided room and board, but also books, uniforms, and twenty-five dollars a month. This possibility must have seemed appealing, especially for those who wanted to prove their value as patriotic citizens.

7 Many continued their voting rights advocacy during World War I. In 1917, New York became the twelfth state to allow women to vote in all elections, and the first state in the Northeast. NAWSA also secured the largest single donation in the movement's history when newspaper editor Miriam Leslie, the wife of publisher Frank Leslie, died; they needed the money to continue their campaign. The National Woman's Party, founded in 1916, attracted media attention to the cause with unprecedented - and controversial - pickets of the White House. The NACW fought for the vote through educational efforts to help Black women register. Although suffragists disagreed about which tactics to use, all of the groups organized to win over voters. 
Suffragists - and women more broadly - succeeded in demonstrating the centrality of their work to the war effort. On September 30, 1918, President Woodrow Wilson encouraged the Senate to approve the $19^{\text {th }}$ Amendment. He confirmed that "We have made partners of the women in this war" and that "This war could not have been fought, either by the other nations engaged or by America, if it had not been for the services of the women." He urged Senators to recognize the measure as "vital to the winning of the war" (Wilson W., 1918). Wilson's speech was not enough to win support.

However, within days of Wilson's address, the flu hit Washington, DC. Public gathering spots closed. The Speaker of the House caught it. The House of Representatives closed their public galleries, and the rest of the Capitol quickly followed suit ("Sick Days," 1918). As the flu swept the city, political work slowed down. That October of 1918, suffragists like Florence Huberwald could do little but watch everything close.

Work paused for many, but women were once again called to action. ${ }^{1}$ Nurses who had trained to care for soldiers during World War I applied their skill to flu patients. The crisis provided new opportunities yet again. During the war, the American Red Cross officially had agreed to deploy Black women to Europe to nurse wounded soldiers, but they never did. The flu pandemic forced them to allow women of color to work for them. For Black nurses, the pandemic provided valuable opportunities for professional advancement (Jones M. and Saines M., 2019).

11 Suffragists adapted too. They donned masks and sat further apart at their meetings. They cancelled some plans, but they still wrote letters to officials, published their newspapers to keep supporters on task, and distributed articles and images to the press. The National Woman's Party continued protesting outside the White House. They started watchfires and burned pieces of paper inscribed with President Wilson's promises about democracy. The cycle of arrests, imprisonment, and hunger strikes continued to draw attention to the cause.

The flu lingered on through the winter of 1918, but cases decreased in the spring, allowing Americans to focus on other issues. In June 1919, the Senate approved the $19^{\text {th }}$ Amendment and sent it to the states for ratification. By the following August, suffragists had secured the required 36 states to make the amendment part of the Constitution.

13 The time between President Wilson's address in September 1918 and the Senate's approval in June 1919 had always puzzled me. What had changed? In 1918, Americans elected new Senators who took office in 1919. But now I also have a far better understanding of the disruption caused by a pandemic. Work was delayed to focus on the public health crisis. During all of this, female caregivers proved themselves as essential workers. Professional nurses monitored patients, and many women similarly cared for ill family members and friends, vital members of their communities. Their work during the war was not enough to secure the Senate's support, but perhaps support for the $19^{\text {th }}$ Amendment rose as women nursed voters and politicians back to health. The suffragists' visual campaign suggested this caregiving work was women's work, and pandemic offered women an opportunity to prove themselves as valuable citizens. 


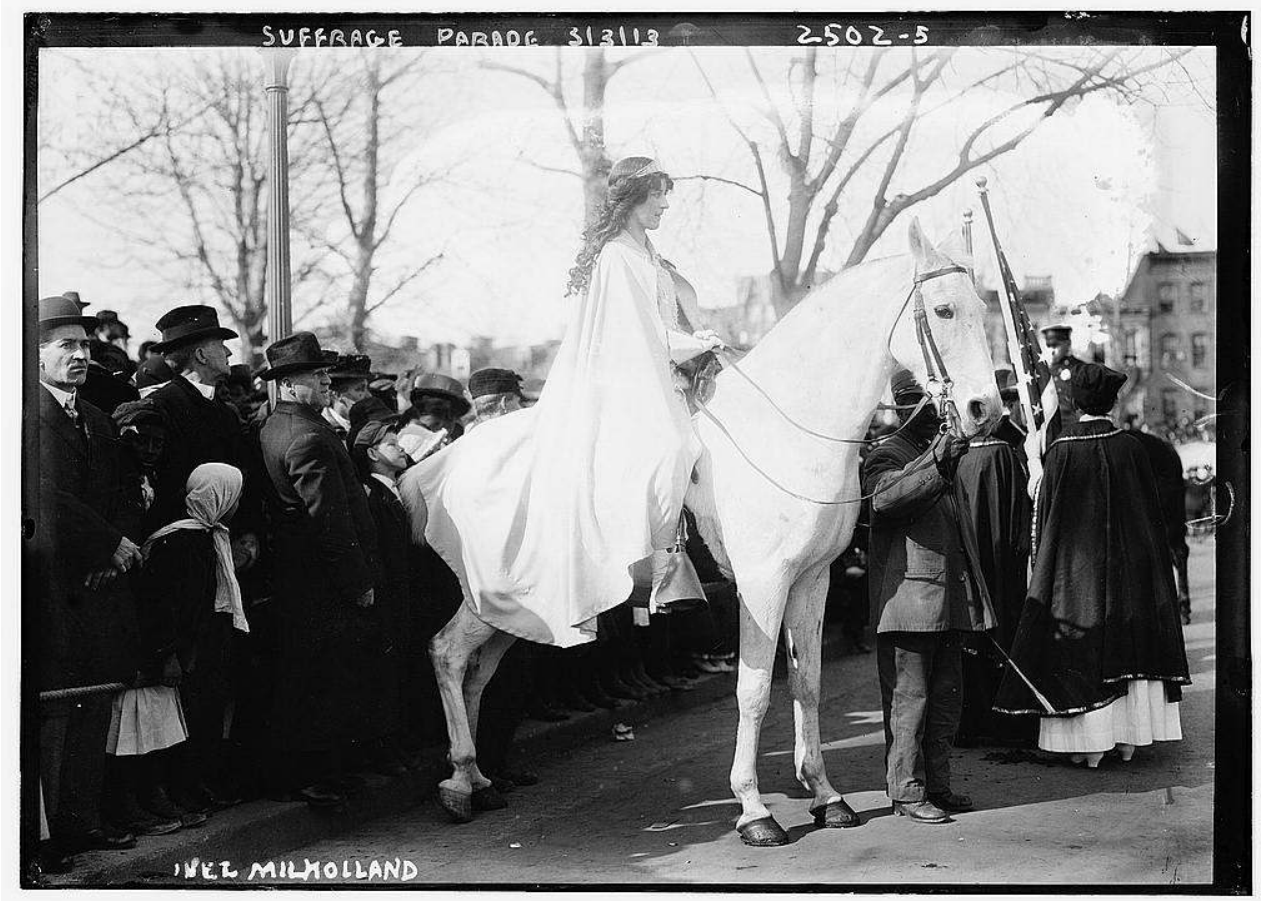

1913, photograph, Library of Congress

14 The suffragists' efforts to turn a moment of crisis into an opportunity for change is compelling and resonates today. In 2020, Americans similarly adapted their social justice protests. During a peak in Black Lives Matter activism in June 2020, protestors marched. This time, they wore masks and tried to social distance. One Black activist, Brianna Noble, rode a horse through the streets of Oakland, California. Photographs of her on the horse went viral. They recalled popular photographs of the famous suffragist Inez Milholland, riding a white horse as the herald for the 1913 parade in Washington, DC. Additionally, the National Woman's Party had made the White House an important place for protests in 1917. In summer 2020, activists continued that tradition by creating Black Lives Matter Plaza. The street lines the park where suffragists had once burned President Wilson's words.

No physical monument commemorates the female nurses and caregivers during World War I or the flu pandemic of 1918 , but perhaps the $19^{\text {th }}$ Amendment is an even more valuable monument to them. The suffragists altered their plans to secure the $19^{\text {th }}$ Amendment, and the people who arranged programs to recognize them for the 2020 centennial did too. This summer's virtual talks often attracted far more attendees than in-person meetings would have, sometimes far more than the space would have allowed. Online programs presented excerpts of delightful suffrage musicals, new documentaries, and outstanding panels of voting rights scholars to viewers all over the world. Many of us have worked to make the most of this exciting time in women's history. Hopefully, like the women's rights activists of the past, we too have demonstrated that moments of crisis present moments of possibility. 


\section{BIBLIOGRAPHY}

“Influenza Mars Suffrage Plans,” New Orleans Times-Picayune, October 10, 1918.

Jones, Marian Moser, and Matilda Saines, "The Eighteen of 1918-1919: Black Nurses and the Great Flu Pandemic in the United States," American Journal of Public Health, vol. 109, nº 6 (April 18, 2019): 877-884, https://doi.org/10.2105/AJPH.2019.305003, accessed October 8, 2020.

“Sick Days," United States House of Representatives History, Art, and Archives, December 17, 2018, https://history.house.gov/Blog/2018/December/12-14-Flu, accessed October 8, 2020.

Wilson, Woodrow, “Address to the Senate on the $19^{\text {th }}$ Amendment," September 30, 1918.

\section{NOTES}

1. For more, see Alisha Haridasani Gupta, "How the Spanish Flu Almost Upended Women's Suffrage," The New York Times, April 28, 2020, sec. U.S., https://www.nytimes.com/2020/04/28/ us/spanish-flu-womens-suffrage-coronavirus.html; Suyin Haynes, "'Persevere Through the Highs and Lows.' What We Can Still Learn From the Suffragists Who Fought for the Right to Vote During the 1918 Flu Pandemic," TIME, June 3, 2020, https://time.com/5833604/1918-flu-pandemicwomen-suffrage-movement/.

\section{AUTHOR}

\section{ALLISON K. LANGE}

Wentworth Institute of Technology 